\title{
Cold-inducible RNA-binding protein migrates from the nucleus to the cytoplasm under cold stress in normal human bronchial epithelial cells via TRPM8-mediated mechanism
}

\author{
Liang-Ping Mao" ${ }^{1 \#}$, Yan Jiao ${ }^{1 \#}$, Jian-Hua Xiang ${ }^{1 \#}$, Xin-Wei Luo ${ }^{1}$, Qian $\mathrm{He}^{1}$, Dan-Hua Ran $^{2}, \mathrm{Qing}^{\mathrm{Xu}}{ }^{3}$, \\ Chun-Hui Lang ${ }^{4}$, Ling-Xiu Chen ${ }^{1}$
}

${ }^{1}$ Department of Respiratory and Critical Care Medicine, Chongqing University Three Gorges Hospital, Chongqing, China; ${ }^{2}$ Department of Respiratory and Geriatrics Medicine, Chongqing Public Health Medical Center, Chongqing, China; ${ }^{3}$ Department of Respiratory and Critical Care Medicine, Eastern Hospital, Sichuan Provincial Medical Sciences Academy \& Sichuan Provincial People’s Hospital, Chengdu, China; ${ }^{4}$ Department of Clinical Nutrition, Chongqing University Three Gorges Hospital, Chongqing, China

Contributions: (I) Conception and design: LX Chen; (II) Administrative support: LX Chen, Q Xu, DH Ran, XW Luo; (III) Provision of study materials or patients: Y Jiao, Q Xu, Q He, LP Mao; (IV) Collection and assembly of data: Y Jiao, Q Xu, Q He, JH Xiang, LP Mao; (V) Data analysis and interpretation: LP Mao, Y Jiao, JH Xiang, CH Lang; (VI) Manuscript writing: All authors; (VII) Final approval of manuscript: All authors.

"These authors contributed equally to this work and should be regarded as co-first authors.

Correspondence to: Ling-Xiu Chen. Department of Respiratory and Critical Care Medicine, Chongqing University Three Gorges Hospital, No. 165, Xincheng Road, Wanzhou District, Chongqing 404000, China. Email: 549482835@qq.com; Chun-Hui Lang. Department of Clinical Nutrition, Chongqing University Three Gorges Hospital, No. 165, Xincheng Road, Wanzhou District, Chongqing 404000, China. Email: langchunhui87@163.com.

Background: Cold-inducible RNA-binding protein (CIRP or hnRNP A18) is a multifunctional stressresponsive protein. Our previous study demonstrated that cold stress increased CIRP expression and migrated from the nucleus to the cytoplasm in airway epithelial cells. However, the mechanism through which CIRP migrates from the nucleus to the cytoplasm upon cold stress remains unknown.

Methods: The expression of CIRP in the bronchial epithelium was examined using immunofluorescence, real-time polymerase chain reaction (RT-PCR), and Western blotting. The expression of inflammatory factors interleukin-1 $\beta$ (IL-1 $\beta$ ), interleukin-6 (IL-6), interleukin-8 (IL-8), and tumor necrosis factor- $\alpha(\mathrm{TNF}-\alpha)$ were detected by ELISA and RT-PCR. Transient receptor potential melastatin 8 (TRPM8) receptor function was characterized by $\mathrm{Ca}^{2+}$ imaging.

Results: Cold stress upregulated the expression of CIRP, inflammatory factors and promoted the translocation of CIRP from the nucleus to the cytoplasm in normal human bronchial epithelial (NHBE) cells. Cold stress activated the TRPM8/(Ca $\left.{ }^{2+}\right) / \mathrm{PKC} \alpha /$ glycogen synthase kinase $3 \beta$ (GSK3 $\beta$ ) signaling cascade, and that inhibition of this signaling pathway attenuated the migration of CIRP from the nucleus to cytoplasm but did not decrease its overexpression induced by cold stress. Knocked down CIRP expression or blocked CIRP migration between the nucleus and cytoplasm significantly decreased inflammatory factor expression.

Conclusions: These results indicate that cold stress leads to the migration of CIRP from the nucleus to the cytoplasm with alteration of expression, which are involved in the expression of inflammatory factors (IL-1 $\beta$, IL-6, IL-8 and TNF- $\alpha$ ) induced by cold air, through TRPM8/Ca ${ }^{2+} / \mathrm{PKC} \alpha / G S K 3 \beta$ signaling cascade.

Keywords: Cold-inducible RNA-binding protein (CIRP); cold stress; migration; transient receptor potential melastatin 8 (TRPM8); glycogen synthase kinase $3 \beta$ (GSK3 $\beta$ )

Submitted Jul 16, 2021. Accepted for publication Sep 16, 2021.

doi: $10.21037 /$ atm-21-4447

View this article at: https://dx.doi.org/10.21037/atm-21-4447 


\section{Introduction}

The cold-inducible RNA-binding protein (CIRP or hnRNP A18) belongs to a group of cold-shock proteins (1) and contains 172 amino acid residues (2). CIRP, the first cold-shock protein identified in mammals (3), has various biological functions. CIRP can be enhanced by stressors, including mild cold temperature (4,5), UV irradiation (6), hypoxia (7), and osmotic pressure (8). Additionally, CIRP protects cells from death induced by genotoxic stress and inhibits UV- and hydrogen peroxide $\left(\mathrm{H}_{2} \mathrm{O}_{2}\right)$-induced cell apoptosis (9). However, several studies have revealed that CIRP released from cells into circulation promotes inflammation, contributing to poor prognosis in brain inflammation (10), hemorrhagic shock, and sepsis (11). In addition, the spatial distribution of CIRP is not fixed. Originally, CIRP was detected in the nucleus of fibroblastic cells and induced by hypothermic shock (12). Nishiyama et al. and Matsumoto et al. then observed CIRP in the cytoplasm of human spermatid cells (13) and Xenopus oocytes (14), respectively. Further, De Leeuw et al. revealed that CIRP translocated from the nucleus to the cytoplasm in response to osmotic stress (15). These data imply that the localization of CIRP is subjected to cell type and the cell type-specific response to diverse stressors.

Our previous study demonstrated that cold stress increased CIRP expression and mediated airway mucin production through toll-like receptor 4 (TLR4)/nuclear factor- $\kappa \mathrm{B}(\mathrm{NF}-\kappa \mathrm{B})$ signaling in normal human bronchial epithelial (NHBE) cells (16). While CIRP is mainly localized in the nucleus, TLR4 is on the plasma membrane and NF- $\mathrm{KB}$ is a cytoplasmic signaling molecule. Therefore, we speculated that under cold stress, CIRP migrated from the nucleus to the cytoplasm in human bronchial epithelial (16HBE) cells.

CIRP consists of a highly conserved RNA-recognition motif (RRM) in the $\mathrm{N}$-terminal and a less conserved arginine-glycine-rich (RGG) domain in the C-terminal, which is a nuclear localization signal and associated with nucleocytoplasmic shuttling (17). Previous studies have reported that CIRP migrates from the nucleus to cytoplasmic stress granules through a methylationdependent mechanism (14). Other data have confirmed that glycogen synthase kinase $3 \beta$ (GSK3 $\beta$ ), a serine/ threonine kinase, upregulates CIRP transcription, increases CIRP protein phosphorylation level, and facilitates its translocation to the cytoplasm (18). However, the mechanism through which CIRP migrates from the nucleus to the cytoplasm upon cold stress in airway epithelial cells remains unknown.

The discovery of the transient receptor potential (TRP) family of thermosensitive ion channels revealed a new biological mechanism for temperature sensing $(19,20)$. TRP melastatin 8 (TRPM8), which is a nonselective calcium $\left(\mathrm{Ca}^{2+}\right)$-permeable cation channel, is mainly expressed on the sensory neurons of the trigeminal ganglia and dorsal root ganglion (19-21). TRPM8 is also expressed on $16 \mathrm{HBE}$ cells (22). Several studies have revealed that TRPM8 can be activated by diverse stimulators, including cold temperature, Icilin, eucalyptol, and menthol $(19,20,23,24)$. Electrophysiological studies have found that TRPM8 activation leads to a large release of intracellular $\mathrm{Ca}^{2+}(20,25,26)$. TRPM8-induced $\mathrm{Ca}^{2+}$ influx activates phospholipase C (PLC), thereby hydrolyzing phosphatidylinositol 4,5-bisphosphate (PIP2), resulting in the generation of inositol trisphosphate (IP3) and diacylglycerol $(27,28)$. Daniels et al. revealed that IP3 promotes $\mathrm{Ca}^{2+}$ release from the endoplasmic reticulum (ER), which is consistent with research findings by Puzianowska-Kuznicka and Kuznicki (29,30). Rebecchi and Pentyala demonstrated that diacylglycerol is an activator of protein kinase C (PKC) (31). Phosphorylated PKC further activates GSK3 $\beta(32,33)$, which has been identified as a contributor to the cytosolic translocation of CIRP protein $(18,34)$. Accordingly, we supposed that cold stress-mediated activation of TRPM8 phosphorylated GSK $3 \beta$ and led to the migration of CIRP protein from the nucleus to the cytoplasm in 16HBE cells under cold stress. We present the following article in accordance with the MDAR reporting checklist (available at https://dx.doi. org/10.21037/atm-21-4447).

\section{Methods}

\section{Reagents}

16HBE cells were purchased from the Experimental Medical Research Center of Guangzhou Medical College (SCC150, Guangzhou, Guangdong, China). Roswell Park Memorial Institute (RPMI) 1640 medium and fetal bovine serum (FBS) were purchased from Gibco (Grand Island, NY, USA). Rabbit anti-CIRP polyclonal antibody was purchased from Proteintech Group, Inc. (10209-2-AP, Chicago, IL, USA). Rabbit anti-TRPM8 anti-body and anti-phosphoPKC (p-PKC) were purchased from Abcam (ab109308 and ab109539, Cambridge, MA, USA). Anti-phospho- 
GSK3 $\beta$ ser 9 (p-GSK3 $\beta$ ser 9) was bought from Bioworld Technology, Inc. (BS4084P, Shanghai, China). Anti-t-PKC (ab107166), anti-t-GSK3 $\beta$ (ab32391), monoclonal anti- $\beta$ actin (ab5694), anti-Lamin B1 (ab133741), and secondary immunofluorescence DyLight 488 antibody (ab96899) were purchased from Abcam. Horseradish peroxidase (HRP)conjugated goat anti-rabbit immunoglobulin $\mathrm{G}(\mathrm{IgG})$ was purchased from Jinqiao Biotech (ZB-2306, Beijing, China). TRPM8 inhibitor BCTC (ab141517), $\left(\mathrm{Ca}^{2+}\right)_{\mathrm{i}}$ chelating agent BAPTA-AM (ab120503), and PKC $\alpha$ specific inhibitor safingol (ab144070) were purchased from Abcam. TRPM8-, GSK3 $\beta$ - and scrambled-small interfering RNA (siRNA) were purchased from Santa Cruz Biotechnology (Santa Cruz, CA, USA). Lipofectamine 2000 was purchased from Invitrogen (Carlsbad, CA, USA). Real-time polymerase chain reaction (RT-PCR) primers were synthesized by Sangon Biotechnology (Shanghai, China).

\section{Cell culture and bypothermia incubation}

The $16 \mathrm{HBE}$ cells were grown on a $12 \mathrm{~mm}$ transwell membrane insert $(0.45 \mu \mathrm{m}$ pore size; Costar, Corning Inc., NY, USA) and maintained at the air-liquid interface. The cells were cultured in RPMI 1640 medium containing $10 \% \mathrm{FBS}$, penicillin $(100 \mathrm{IU} / \mathrm{mL})$, and streptomycin $(100 \mu \mathrm{g} / \mathrm{mL})$ at $37{ }^{\circ} \mathrm{C}$ in a $5 \% \mathrm{CO}_{2}$ humidified incubator. The culture media were refreshed every $2-3$ days. When the cells were $80-90 \%$ confluent, they were passaged with trypsin or ethylenediaminetetraacetic acid (EDTA) and reseeded in the air-liquid interface culture at $1 \times 10^{5} \mathrm{cells} / \mathrm{cm}^{2}$ of density. When the cells reached $80-90 \%$ confluence again after being cultured for another 24-48 hours, they were used for the experiments. For temperature-shift experiments, $16 \mathrm{HBE}$ cells starved by RPMI 1640 without FBS for an additional 24 hours were first incubated at 15 , $18,22,25$, or $32{ }^{\circ} \mathrm{C}$ in a $5 \% \mathrm{CO}_{2}$ humidified incubator for 12 hours. The cells were then harvested for further experiments. For the inhibition experiments, cells were pretreated with BCTC $(15 \mu \mathrm{M})$, BAPTA-AM $(10 \mu \mathrm{M})$, or safingol $(30 \mu M) 30$ minutes before cold air treatment.

\section{siRNA transfection}

The $16 \mathrm{HBE}$ cells were plated at a density of approximately $2 \times 10^{6}$ cells $/ \mathrm{mL}$ in each well of a $24-$ well plate at $60-80 \%$ confluence. The cells were then transfected with $20 \mathrm{nM}$ of siRNA (siCIRP, siTRPM8, siGSK3 $\beta$, or siNT) using Lipofectamine 2000, according to the manufacturer's instructions. Twenty-four hours later, the cells were washed 3 times with PBS and incubated in serum-free RPMI 1640 medium for another 24 hours before cold stimulation.

\section{Cell viability assay}

Cell viability was assessed using a tetrazolium-based (MTT) assay. Cells $\left(5 \times 10^{4}\right.$ cells/well $)$ were seeded in 96-well plates and cultured in $200 \mu \mathrm{L}$ of RPMI 1640 medium under different treatment conditions for the indicated time periods. Next, $20 \mu \mathrm{L}$ of MTT was added, and the plates were incubated at $37^{\circ} \mathrm{C}$ for an additional 4 hours. After incubation, $150 \mu \mathrm{L}$ of dimethyl sulfoxide (DMSO) was added to each well and incubated at room temperature for 10 minutes. Subsequently, the absorbance was measured at $570 \mathrm{~nm}$ with a Sunrise Remote microplate reader (Tecan, Männedorf, Switzerland).

\section{Protein extraction}

Cells in each group were collected and washed 3 times with PBS; the supernatant was removed, and the cells were lysed in radioimmunoprecipitation assay (RIPA) lysis buffer containing a protease inhibitor and phosphatase inhibitor. Samples were then centrifuged at $14,000 \times \mathrm{g}$ for 15 minutes at $4{ }^{\circ} \mathrm{C}$. The supernatants were transferred to new tubes for subsequent analysis. The samples were then tested using a bicinchoninic acid (BCA) protein assay reagent. The quantitative changes in CIRP, TRPM8, PKC $\alpha, \mathrm{p}-\mathrm{PKC} \alpha$, GSK3 $\beta$, and p-GSK3 $\beta$ were tested by western blot, while interleukin-1 $\beta$ (IL-1 $\beta$ ), tumor necrosis factor- $\alpha$ (TNF- $\alpha$ ), interleukin-8 (IL-8), and interleukin-6 (IL-6) were detected by ELISA assay.

\section{Subcellular fractionation}

Cytoplasmic and nuclear extracts were prepared according to the nuclear and cytoplasmic extraction kit guide (BestBio, Shanghai, China). Additionally, all samples were tested using a BCA protein assay reagent. Quantitative changes of CIRP in the nucleus and cytoplasm were measured by western blot.

\section{Western blotting}

The extracted protein samples were separated with SDS-polyacrylamide gel electrophoresis (SDS-PAGE). Subsequently, the proteins were transferred through 
electrophoresis onto polyvinylidene difluoride (PVDF) membranes and blocked with $5 \%$ skimmed milk or $5 \%$ bovine serum albumin (BSA) at room temperature for 1 hour. The PVDF membranes were then probed with specific primary antibodies against CIRP (1:500), TRPM8 (1:200), p-PKC $\alpha$ (1:500), and p-GSK3 $\beta$ (ser 9) (1:500) overnight at $4{ }^{\circ} \mathrm{C}$. After being washed 3 times with phosphate-buffered saline with Tween-20 (PBST) containing $500 \mathrm{~mL}$ of PBS and $250 \mu \mathrm{L}$ of Tween-20, the membranes were incubated with the HRP-conjugated goat anti-rabbit and anti-mouse secondary antibodies $(1: 1,000)$ for 1 hour at room temperature. The blots were developed according to the instructions of the enhanced chemiluminescence (ECL) reagent kit (KeyGen Biotech Co., Ltd., Nanjing, China). Lamin B1 was used as a nuclear envelope marker and $\beta$-actin was used as cytosolic protein or total protein marker. The amount of protein present was normalized with either $\beta$-actin or Lamin B1.

\section{ELISA assay}

After various treatments, the amount of IL-6, IL-8, TNF- $\alpha$, and IL- $1 \beta$ protein was detected according to the guidelines of the ELISA kit (KeyGen Biotech Co., Ltd.) Cell lysates were prepared with PBS at multiple dilutions. A $50 \mu \mathrm{L}$ aliquot of each sample was then incubated with an equal volume of bicarbonate-carbonate buffer at $40^{\circ} \mathrm{C}$ in a 96 -well plate until dry. The plates were washed 3 times with PBS and blocked with $2 \%$ BSA for 1 hour at room temperature followed by incubation with $50 \mu \mathrm{L}$ of the primary antibody (1:200 for mouse IL-1 $\beta$, IL-6, IL-8, and TNF- $\alpha$ antibodies) at $37^{\circ} \mathrm{C}$ for 1 hour. Following a wash step, the plates were incubated with the HRP-conjugated goat anti-mouse $\operatorname{IgG}(1: 5,000)$ for 1 hour at room temperature. The color reaction was performed with a 3,3',5,5'-tetramethylbenzidine peroxidase solution (TMB) and quenched with sulfuric acid $\left(\mathrm{H}_{2} \mathrm{SO}_{4}\right)$. The absorbance was read at $450 \mathrm{~nm}$ using a microplate reader. The results were calculated based on a comparison with standard samples.

\section{RT-PCR}

Total RNA in each group was extracted using TRIzol reagent (Takara Biotechnology Co., Ltd., Dalian, China). Samples with OD260/OD280 ratios between 1.6 and 1.8 were stored at $-20^{\circ} \mathrm{C}$. Subsequently, $2 \mu \mathrm{g}$ of total RNA was used to synthesize complementary DNA (cDNA) using the iScript complementary DNA synthesis kit, and $20 \mathrm{ng}$ cDNA was used for the RT-PCR reaction with iQ SYBR Green supermix on an iCycler (Takara Biotechnology Co., Ltd.). The following primers were prepared: CIRP, forward 5'-ACAGATCATGGCATC AGATGAAGGCAAAC-3' and reverse 5'-TAAGCT TACTCGTTGTGTGTAGCGTAACTG-3'; IL-1 $\beta$, forward 5'-CAGGATGAGGA CATGAGCACC-3' and reverse 5'-CTCTGCAGACTCAAACTCCAC-3'; IL-6, forward 5'-AGTGAGG AACAAGCCAGAGC-3' and reverse 5'-GAGGTGCCCATGCTACATTT-3'; IL-8, forward 5'-CCTGATTTCTGCAGCTCTGT-3' and reverse 5'-AACTTCTCCACAACCCTCTG-3'; TNF- $\alpha$, forward 5'-AGGACTCAGCTTCGACACCA and reverse 5'-CGTCCACAGACTTCCCA TTC-3', and; glyceraldehyde 3-phosphate dehydrogenase (GAPDH), forward 5'-GAAGGTGAAGGTCGGAGT-3' and reverse 5'-GAAG ATGGTGATGGGATTTC-3'. PCR reactions were performed as follows: CIRP, $94{ }^{\circ} \mathrm{C}$ for 1 minute, 30 cycles of $53{ }^{\circ} \mathrm{C}$ for 1 minute, and $72{ }^{\circ} \mathrm{C}$ for 1.5 minutes, followed by 5 minutes of incubation at $72{ }^{\circ} \mathrm{C}$; IL- $1 \beta, 94{ }^{\circ} \mathrm{C}$ for 2 minutes, 28 cycles of $94{ }^{\circ} \mathrm{C}$ for 30 seconds, and $58{ }^{\circ} \mathrm{C}$ for 30 seconds, followed by 10 minutes of incubation at $72{ }^{\circ} \mathrm{C}$; IL-6 and IL-8, $94{ }^{\circ} \mathrm{C}$ for 2 minutes, 28 cycles of $94{ }^{\circ} \mathrm{C}$ for 30 seconds, and $72{ }^{\circ} \mathrm{C}$ for 30 seconds, followed by 10 minutes of incubation at $72{ }^{\circ} \mathrm{C}$, and; TNF- $\alpha, 95^{\circ} \mathrm{C}$ for 30 seconds, 30 cycles of $95^{\circ} \mathrm{C}$ for 5 seconds, and $64^{\circ} \mathrm{C}$ for 30 seconds, followed by 10 minutes of incubation at $72^{\circ} \mathrm{C}$. The comparative Ct method $\left(2^{\Delta \Delta C}\right)$ was used for relative mRNA quantification. GAPDH mRNA was also amplified as an internal control.

\section{Immunofluorescence}

The 16HBE cells from each group were plated at a density of $1 \times 10^{6} / \mathrm{mL}$ in 24 -well plates on a poly-L-lysine coated glass coverslip in each well. The culture media was renewed each day. After reaching 60-80\% confluence, the cells were washed 3 times for 5 minutes with ice-cold PBS. Cells were then fixed with $4 \%$ paraformaldehyde for 20 minutes at room temperature and permeabilized with $0.1 \%$ Triton $\mathrm{X}-100$ for 30 minutes. After a wash step, cells were blocked with $1 \%$ BSA plus $1 \%$ normal goat serum and followed by incubation with anti-CIRP or a mouse anti-MUC5AC antibody $(1: 200)$ overnight at $4{ }^{\circ} \mathrm{C}$. Cells were then rinsed again with PBS (3 times for 10 minutes) and incubated with a FITC-conjugated fluorescent secondary antibody (1:200) in the dark for 1 hour at $37^{\circ} \mathrm{C}$. Finally, the cell nuclei were stained with 4',6-diamidino-2-phenylindole (DAPI). The 
samples were visualized using a TCS-SP2 laser scanning confocal microscope (Leica, Wetzlar, Germany) equipped with ZEN 2009 software for image acquisition and analyses.

\section{Calcium imaging assay}

The concentration of $\left(\mathrm{Ca}^{2+}\right)_{\mathrm{i}}$ was measured by calcium imaging. First, the cell suspensions from each treatment group were collected. Next, $200 \mu \mathrm{L}$ suspensions were loaded with $200 \mu \mathrm{L}$ of $5 \mu \mathrm{M}$ Fluo-3/AM in Hank's balanced salt solution for 30 minutes in the dark at $37^{\circ} \mathrm{C}$. Cell suspensions were then washed twice with D-Hank's solution to remove the extracellular fluo-3/AM. Laser scanning confocal microscope (Leica) analysis was performed to determine intracellular $\mathrm{Ca}^{2+}$ concentration which was indicated by fluo-3-fluorescence and expressed as the fluorescence intensity.

\section{Statistical analysis}

Data are presented as the mean $\pm \mathrm{SD}$ of five independent experiments. All experiments were independently repeated 5 times. SPSS statistics version 22.0 software was used to analyze the data and one-way analysis of variance (ANOVA) followed by Bonferroni analysis were performed to evaluate the levels of difference between groups. $\mathrm{P}$ values $<0.05$ were considered statistically significant.

\section{Results}

\section{Cell viability}

The cell viability of each group was detected by MTT assay. We found that none of the conditions used in our study showed significant influence on cell viability.

\section{Cold stress induced CIRP upregulation in 16HBE cells}

CIRP is induced by multiple environmental stresses, including cold temperature, hypoxia, UV irradiation, and osmotic pressure. The present study further verified that cold stress enhances the expression of CIRP protein and mRNA. Our data showed that the expression of CIRP protein and mRNA were both increased markedly by mild cold stress $\left(32-18{ }^{\circ} \mathrm{C}\right)$, peaking at $18{ }^{\circ} \mathrm{C}$, but the increase was reduced under severe cold treatment of $15{ }^{\circ} \mathrm{C}$ (Figure $1 A, 1 B$ ). Further, when $16 \mathrm{HBE}$ cells were exposed to cold air (a temperature of $18{ }^{\circ} \mathrm{C}$ ), we found that cold stress- induced CIRP protein expression in a time-dependent manner, with the increase beginning at 4 hours and peaking at 12 hours (Figure 1C). Meanwhile, CIRP mRNA expression also began to increase at 4 hours, but the plateau expression was observed at 8 hours and persistent for 12 hours (Figure 1D). based on these results, a temperature of $18{ }^{\circ} \mathrm{C}$ for 12 hours was selected as the best reaction condition for subsequent experiments because according to the previous observation, we assume that this is the best condition to observe CIRP protein expression increase.

\section{Cold-air triggered TNF- $\alpha, I L-1 \beta, I L-6$, and IL- 8 expression and CIRP may participate in inflammatory responses induced by cold air in $16 \mathrm{HBE}$ cells}

Previous studies have confirmed that exposure to cold air can aggravate chronic airway inflammation diseases, such as asthma and chronic obstructive pulmonary disease (COPD), by triggering cold airway inflammation $(35,36)$. In this paper, again we confirmed that cold air triggered airway inflammatory responses and explored the underlying mechanism. Our data showed that the expression of TNF- $\alpha$, IL- $1 \beta$, IL- 6 , and IL- $8 \mathrm{mRNA}$ and protein were significantly increased by cold stress $\left(18^{\circ} \mathrm{C}\right)$ compared to the control group $\left(37^{\circ} \mathrm{C}\right)$, which indicated that cold stress could trigger airway inflammation. In addition, we found that compared with the control nontargeting siRNA (siNT) and no transfection groups, increased expression of TNF- $\alpha$, IL-1 $\beta$, IL-6, and IL-8 mRNA and protein were significantly decreased by CIRP siRNA, which attenuated CIRP protein expression effectively (Figure 2). These findings demonstrated that cold air could trigger TNF- $\alpha$, IL- $1 \beta$, IL-8, and IL-6 expression, and that CIRP was involved in the expression of these inflammatory factors.

\section{Cold stress promoted CIRP migration from the nucleus to the cytoplasm in $16 \mathrm{HBE}$ cells}

Previous studies have reported that the spatial distribution of CIRP is based on different environmental stressors and is subjected to the environment in which the cells are located. We further observed the spatial distribution of the CIRP before and after cold stimulation using confocal laser-scanning microscopy (CLSM). The CLSM showed that cold stress enhanced the expression of CIRP, which was mainly observed in the cytoplasm (Figure $3 A$ ). We further determined the level of CIRP expression at the cellular and subcellular levels, respectively. At the cellular 

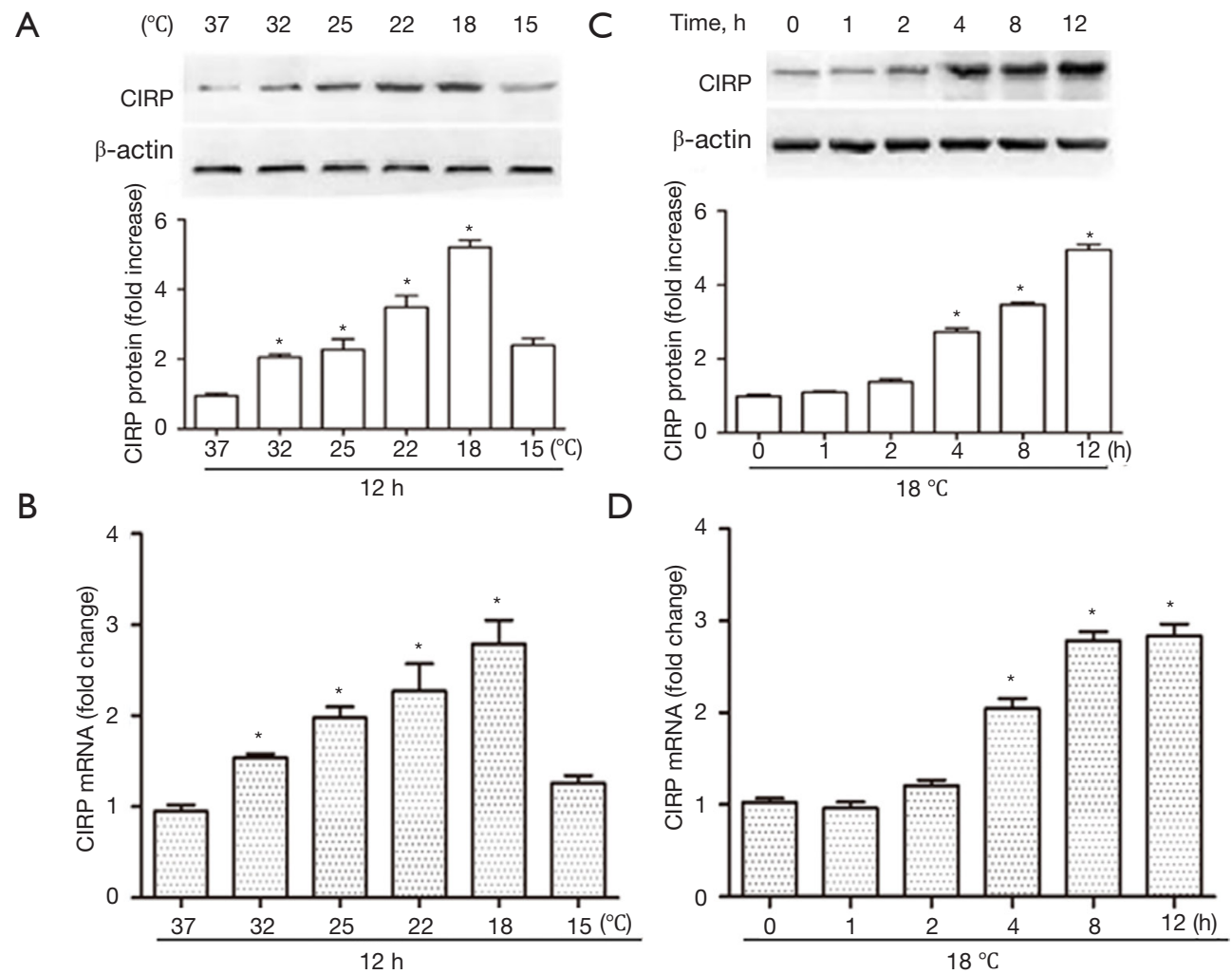

Figure 1 Effect of cold air on CIRP expression in $16 \mathrm{HBE}$ cells. Cells were cultured at various temperatures $\left(37,32,25,22,18\right.$, or $\left.15{ }^{\circ} \mathrm{C}\right)$ and for various times $(0,1,2,4,8$, or 12 hours). Total RNA and protein of CIRP were collected. The levels of CIRP mRNA and protein were then measured by RT-PCR and western blotting, respectively. (A) Effect of decreasing temperatures on CIRP protein production over 12 hours. The expression of CIRP protein increased markedly in response to mild cold treatment $\left(32-18{ }^{\circ} \mathrm{C}\right)$, peaking at $18{ }^{\circ} \mathrm{C}$. Compared with $18{ }^{\circ} \mathrm{C}$, the increase induced by severe cold treatment $\left(15^{\circ} \mathrm{C}\right)$ was reduced. (B) Effect of decreasing temperatures on CIRP mRNA expression. The expression of CIRP mRNA increased markedly in response to mild cold treatment $\left(32-18{ }^{\circ} \mathrm{C}\right)$ and peaked at $18{ }^{\circ} \mathrm{C}$, but severe cold treatment $\left(15^{\circ} \mathrm{C}\right)$ did not affect the levels of CIRP mRNA. (C) Effect of cold air $\left(18^{\circ} \mathrm{C}\right)$ treatment for various time intervals on CIRP protein production. The expression of CIRP was increased in a time-dependent manner. (D) Effect of cold air $\left(18{ }^{\circ} \mathrm{C}\right)$ treatment for various time intervals on CIRP mRNA expression. CIRP mRNA increased markedly starting at 4 hours, and this increase peaked at 8 hours and persisted for 12 hours. ${ }^{*} \mathrm{P}<0.01$ compared with control (temperature $37^{\circ} \mathrm{C}$ or time 0 ). These data are presented as the means $\pm \mathrm{SD}$ ( $\mathrm{n}=5$ ). CIRP, cold-inducible RNA-binding protein; 16HBE, human bronchial epithelial; RT-PCR, real-time polymerase chain reaction.

level, western blot assay demonstrated that cold treatment markedly increased CIRP expression (Figure 3B). At the subcellular level, as shown in Figure 3C,3D, CIRP was mainly detected in the nucleus rather than the cytoplasm in the control group. Conversely, in the cold group, CIRP expression in the cytoplasm was higher than in the nucleus, which was consistent with the CLSM results. These results suggested that cold stress increased CIRP expression and also promoted the migration of CIRP from the nucleus to the cytoplasm in 16HBE cells.

\section{Functional analysis of TRPM8 under cold stress in 16HBE cells}

To measure the characteristic function of the TRPM8 channel, TRPM8 defective 16HBE cells were generated by transfection with siTRPM8. 16HBE cells were pretreated with TRPM8 inhibitor BCTC and the $\left(\mathrm{Ca}^{2+}\right)_{\mathrm{i}}$ chelating agent BAPTA-AM for 30 minutes. The cells were then given $18{ }^{\circ} \mathrm{C}$ cold air stress for 12 hours. The $\left(\mathrm{Ca}^{2+}\right)_{i}$ was measured by calcium imaging. As shown in Figure 4, cold stress significantly increased intracellular $\mathrm{Ca}^{2+}$, and increases 
A

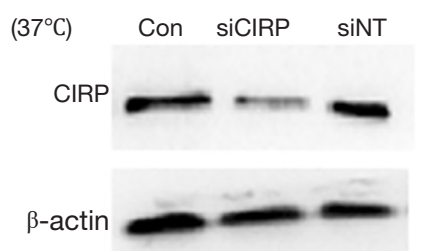

B3

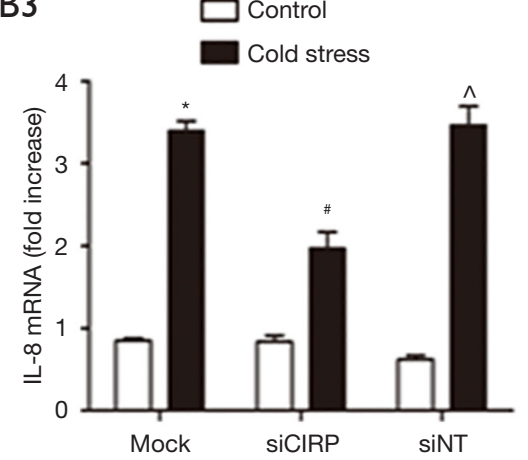

C2
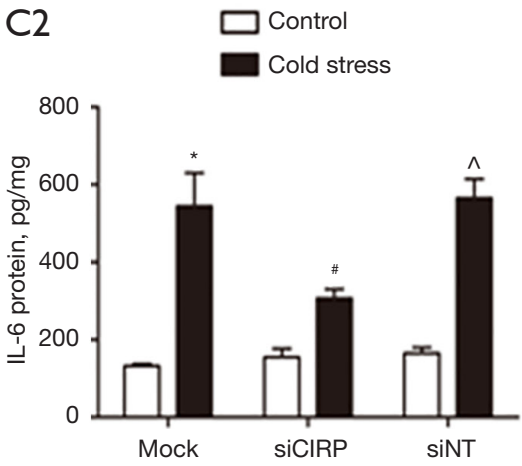

B I

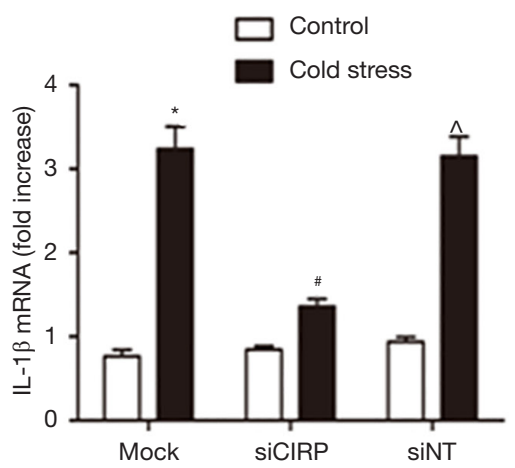

B4

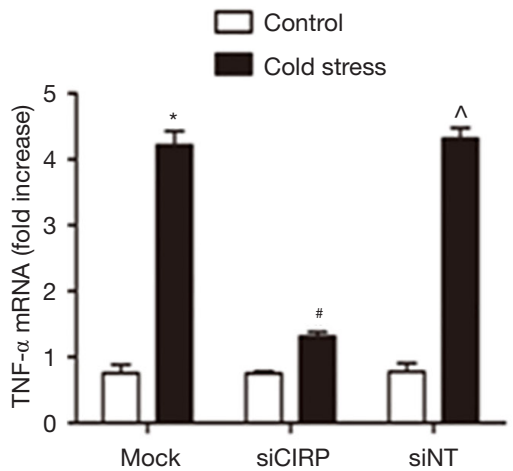

C3

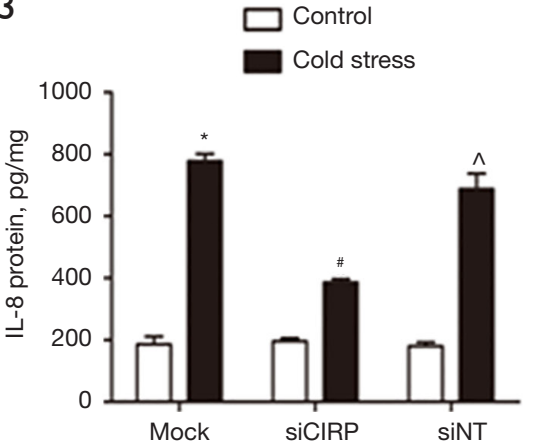

B2
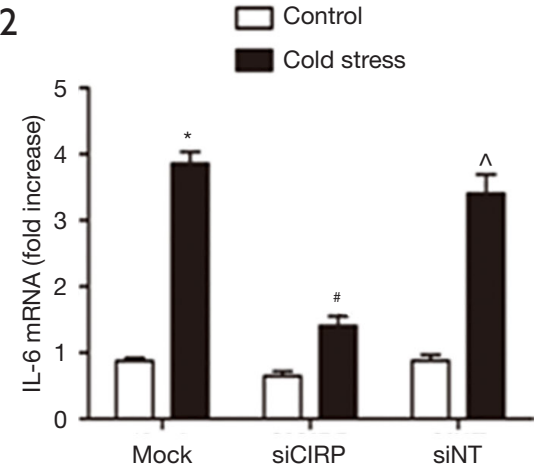

CI
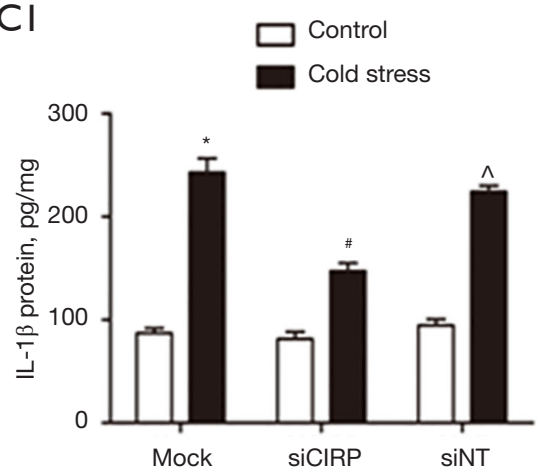

C4
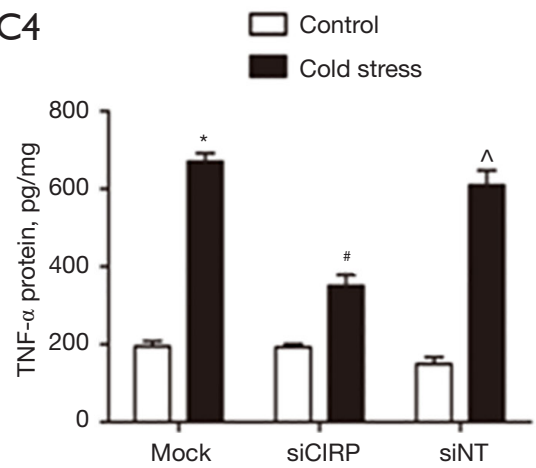

Figure 2 The effect of CIRP downregulation on inflammatory factors (IL-1 $\beta$, IL-6, IL-8, and TNF- $\alpha$ ) mRNA and protein expression levels. The $16 \mathrm{HBE}$ cells were transfected with the specific siCIRP or siNT, or left untransfected as the negative control. After transfection, the cells were incubated at $18^{\circ} \mathrm{C}$ (cold stress) or $37^{\circ} \mathrm{C}$ (control) for 12 hours to measure IL-1 $\beta$, IL-6, IL-8, and TNF- $\alpha$ mRNA and protein expression, respectively. (A) Western blotting demonstrated that CIRP expression was notably blocked by siCIRP. (B) The RT-PCR suggested that the transfection of siCIRP significantly attenuated cold stress-induced expression of IL-1 $\beta$, IL-6, IL-8, and TNF- $\alpha$ mRNA. (C) The ELISA indicated that the expression of IL-1 $\beta$, IL-6, IL-8, and TNF- $\alpha$ protein enhanced by cold air was decreased markedly by siCIRP. ${ }^{*} \mathrm{P}<0.05$ vs. control group cells; ${ }^{\#} \mathrm{P}<0.05$ vs. untransfected cells with cold stress stimulation; and $\wedge \mathrm{P}>0.05$ vs. untransfected cells with cold stress stimulation. These data are presented as the means \pm SD $(n=5)$. CIRP, cold-inducible RNA-binding protein; IL- $1 \beta$, interleukin- $1 \beta$; IL-6, interleukin-6; IL-8, interleukin-8; TNF- $\alpha$, tumor necrosis factor- $\alpha$; siRNA, small interfering RNA; siCIRP, siRNA targeting CIRP; siNT, non-targeting siRNA; RT-PCR, real-time polymerase chain reaction. 
A

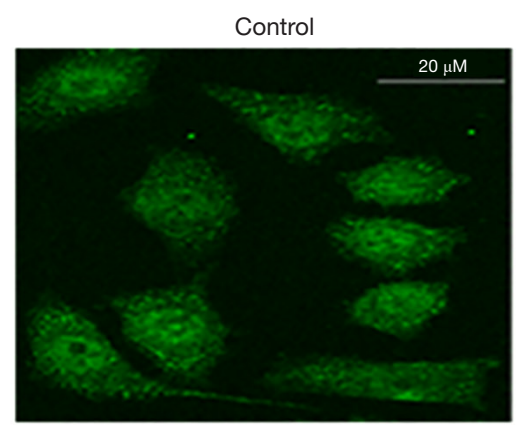

B

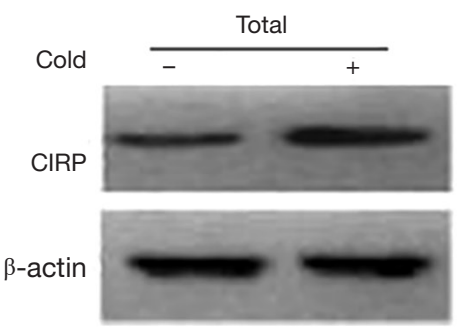

C

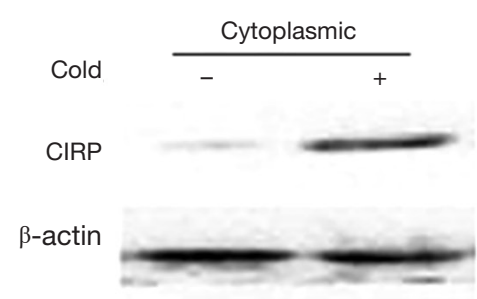

D

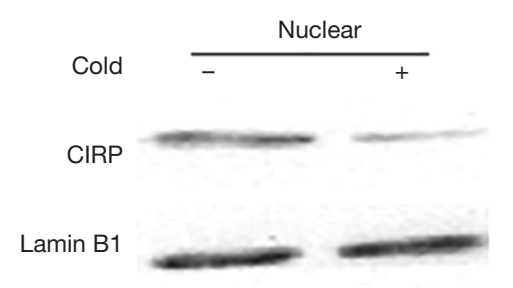

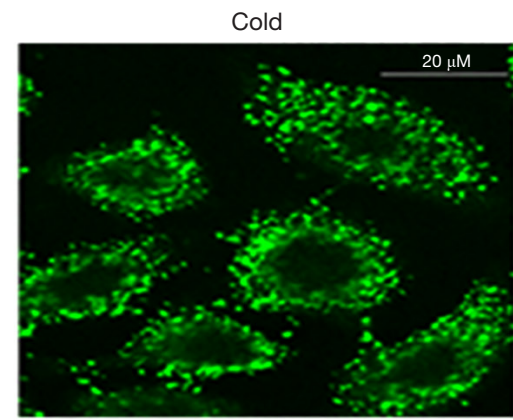
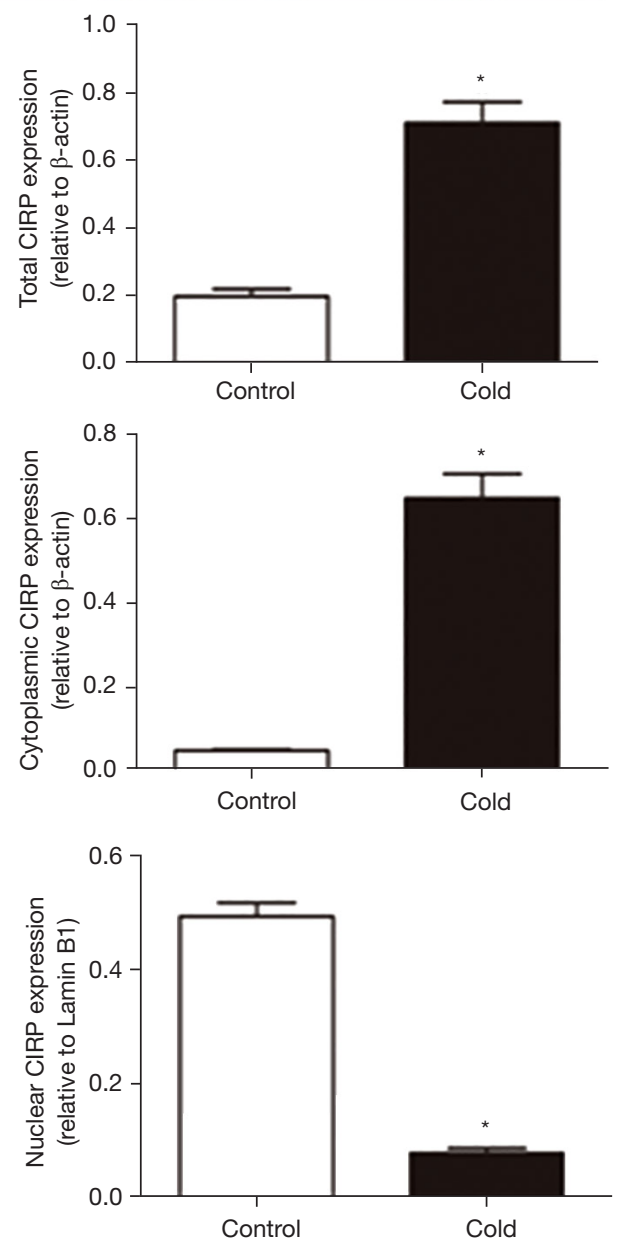

Figure 3 The expression of CIRP in $16 \mathrm{HBE}$ cells treated with or without cold stress $\left(18^{\circ} \mathrm{C}\right)$ for 12 hours. The expression and localization of CIRP were detected by CLSM and western blot. (A) CLSM showed that the expression of CIRP was notably increased when the cells were exposed to cold stress and was mainly located in the cytoplasm. The cellular CIRP protein expression in each group was detected using the CIRP antibody and fluorescein isothiocyanate (green) goat anti-mouse IgG, magnification $\times 800$. (B) Total protein was prepared, and CIRP expression was measured by western blot analysis. Anti- $\beta$-actin was used as the marker. Higher CIRP levels were observed in the cold stress group. (C,D) Cytosolic and nuclear fractions were prepared, and the expression levels of CIRP in each fraction were analyzed by western blot. Anti-Lamin B1 and anti- $\beta$-actin were used as markers of nuclear and cytoplasmic proteins, respectively. In subcellular fractionation, the expression of cytoplasmic CIRP was markedly increased, while nuclear CIRP was decreased after cold stress treatment. ${ }^{*} \mathrm{P}<0.05$ vs. control group cells. These data are presented as the means \pm SD $(n=5)$. CIRP, cold-inducible RNA-binding protein; 16HBE, human bronchial epithelial; CLSM, confocal laser-scanning microscopy. 


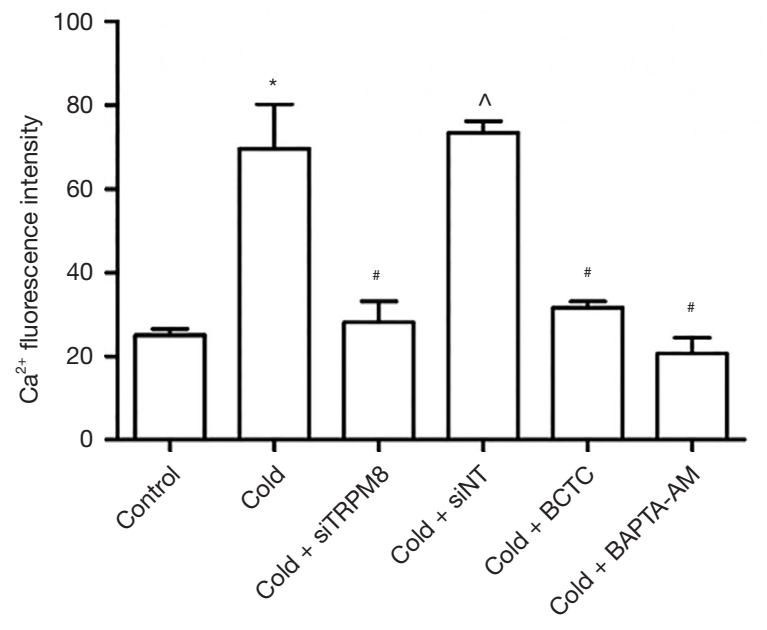

Figure 4 The $\left(\mathrm{Ca}^{2+}\right)_{\mathrm{i}}$ in different experimental groups was measured by calcium imaging. The $\mathrm{Ca}^{2+}$ concentration indicated by fluo-3-fluorescence is shown as fluorescence intensity. The $\mathrm{Ca}^{2+}$ concentration was increased by cold air and decreased by pretreatment with siTRPM8, TRPM8 inhibitor BCTC, and $\left(\mathrm{Ca}^{2+}\right)_{\mathrm{i}}$ chelating agent BAPTA-AM. ${ }^{*} \mathrm{P}<0.01$ compared with the control group; ${ }^{~} \mathrm{P}<0.05$ compared with the cold stress group; and ${ }^{\wedge} \mathrm{P}>0.05$ compared with the cold stress group. These data are presented as the means $\pm \operatorname{SD}(n=5)$. TRPM8, transient receptor potential melastatin 8 .

in $\mathrm{Ca}^{2+}$ induced by cold stress were significantly decreased by siTRPM8, BCTC, and BAPTA-AM but not by siNT. These results indicated that cold stress, at least partially, activated TRPM8, which led to an increase in $\left(\mathrm{Ca}^{2+}\right)_{i}$.

\section{The effect of cold stress on the TRPM8/PKC $\alpha / G S K 3 \beta$ signaling pathway in $16 \mathrm{HBE}$ cells}

As shown in Figure 5, western blot clearly demonstrated that TRPM8- and GSK3 $\beta$-siRNA effectively attenuated the expression of TRPM8 and GSK3 $\beta$ protein compared to the control group, while siNT did not have the same effect (Figure 5A,5B). Moreover, cold stress significantly increased the phosphorylated levels of PKC $\alpha$ and GSK3 $\beta$ (Figure $5 C, 5 D,{ }^{*} \mathrm{P}<0.05$ vs. control). In contrast, the TRPM8-siRNA markedly attenuated the increased phosphorylation of PKC $\alpha$ and GSK3 $\beta$ by cold stress (Figure $5 C, 5 D,{ }^{*} \mathrm{P}<0.05$ vs. cold group). Further, we found that pretreatment with TRPM8 inhibitor BCTC, $\left(\mathrm{Ca}^{2+}\right)_{\mathrm{i}}$ chelating agent BAPTA-AM, or PKC $\alpha$ specific inhibitor safingol, significantly attenuated the phosphorylation level of $\mathrm{PKC} \alpha$ as well as the phosphorylation level of GSK3 $\beta$. The above findings illustrated that cold stress, at least partially, facilitated the activation of PKC $\alpha$ and GSK3 $\beta$ in a TRPM8-dependent manner.

\section{The TRPM8/PKCa/GSK3ß signaling pathway may be involved in cold-mediated migration of CIRP from the nucleus to the cytoplasm in $16 \mathrm{HBE}$ cells}

At the cellular level, the TRPM8-siRNA, BCTC, BAPTA$A M$, safingol, and GSK3 $\beta$-siRNA groups did not exhibit decreased expression of the CIRP increased by cold stress compared to the cold group (Figure $6 A,{ }^{\#} \mathrm{P}>0.05$, there was no statistical significance). At the subcellular level, after pretreatment with siTRPM8, BCTC, BAPTA-AM, safingol, and siGSK3 $\beta$, the expression of CIRP in the cytoplasm was decreased, while the expression of CIRP in the nucleus was markedly increased (Figure $6 B, 6 C,{ }^{\#} \mathrm{P}<0.05$ ). These data indicated that the blocking of the TRPM8/ $\mathrm{PKC} \alpha / \mathrm{GSK} 3 \beta$ signaling pathway suppressed migration of CIRP from the nucleus to the cytoplasm but did not inhibit the overexpression of CIRP induced by cold stress.

In addition, the alternation in CIRP expression before and after cold stress was directly observed by CLSM. Compared with the control, CLSM (Figure 7) showed that cold stress significantly increased CIRP protein expression, which was enriched in the cytoplasm. However, compared with the cells treated with cold stress and those treated with non-targeting siRNA, the cells treated with TRPM8siRNA, BCTC, BAPTA-AM, safingol, and GSK3 $\beta$ siRNA displayed a significant reduction of cytosolic CIRP expression and higher nuclear CIRP expression. Collectively, these findings confirmed that cold stress induced CIRP overexpression and promoted CIRP migration from the nucleus to the cytoplasm at least partly via the TRPM8/ $\mathrm{PKC} \alpha / \mathrm{GSK} 3 \beta$ signaling pathway.

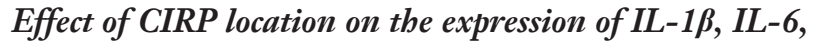 $I L-8$, and TNF- $\alpha$ induced by cold stress in $16 H B E$ cells}

Figure 2 shows that CIRP contributed to cold stressinducible inflammatory cytokine expression. To determine the effect of CIRP location on the expression of inflammatory factors induced by cold stress, we transfected cells with TRPM8-siRNA, GSK3 $\beta$-siRNA, or nontargeting siRNA, or pretreated cells with BCTC, BAPTA- 
A

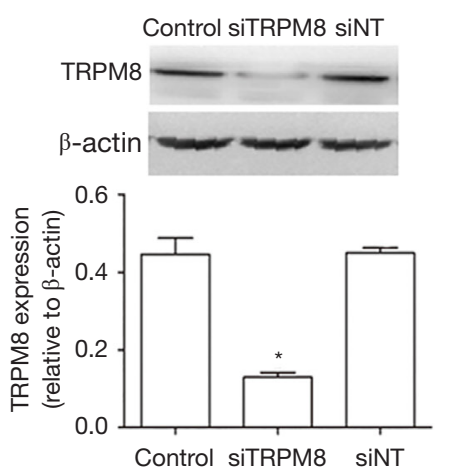

C

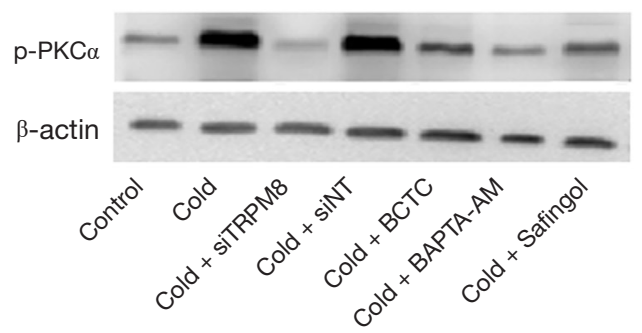

D

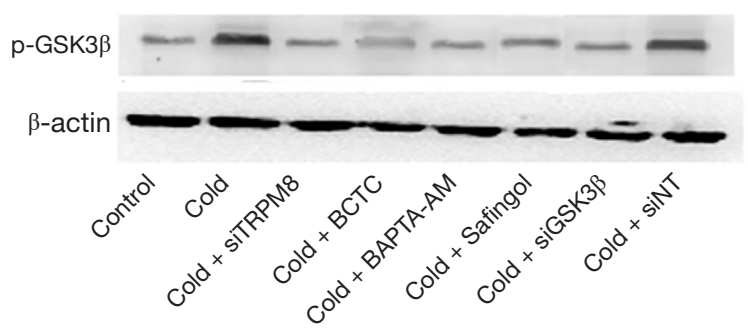

B
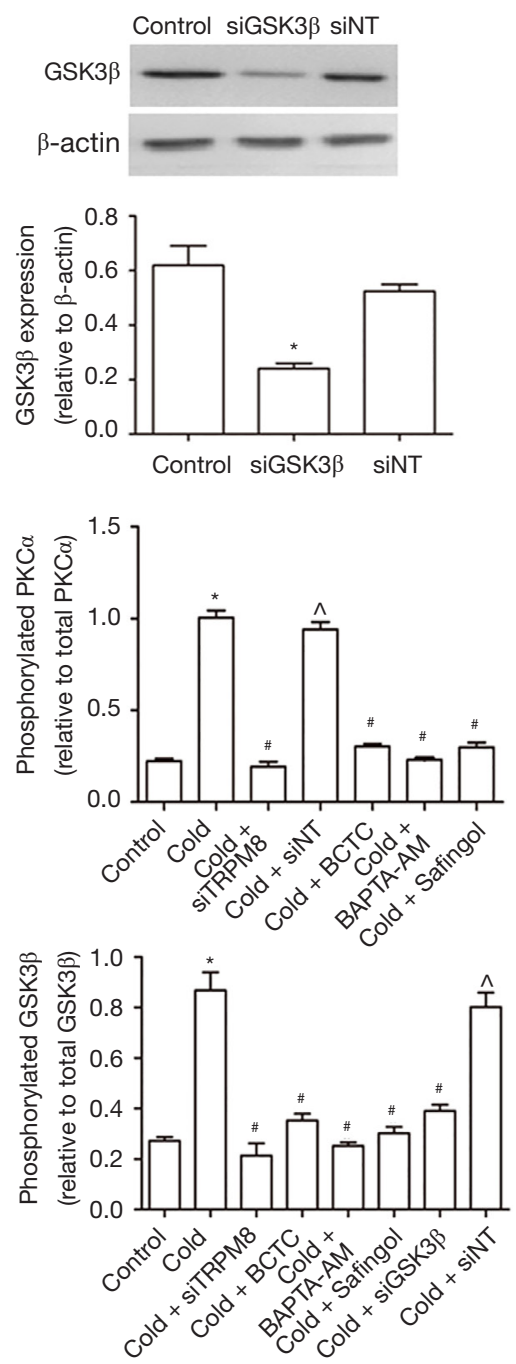

Figure 5 Cold stress-activated PKC $\alpha$-related signaling pathway in 16HBE cells. Cells were transfected with TRPM8-siRNA, GSK3 $\beta$ siRNA, or siNT, or pretreated with TRPM8 inhibitor BCTC $(15 \mu \mathrm{M}),\left(\mathrm{Ca}^{2+}\right)_{\mathrm{i}}$ chelating agent BAPTA-AM $(10 \mu M)$, or PKC $\alpha$ specific inhibitor safingol $(30 \mu \mathrm{M})$ for 30 minutes before cold stress $\left(18^{\circ} \mathrm{C}, 12\right.$ hours). The expression levels of TRPM8, PKC $\alpha$, and GSK3 $\beta$ were measured by western blot. Anti- $\beta$-actin was used as the marker. (A,B) TRPM8 and GSK3 $\beta$ were decreased by TRPM8-siRNA and GSK3 $\beta$ siRNA, respectively, but not by siNT. (C) TRPM8-siRNA, BCTC, and BAPTA-AM inhibited the phosphorylation of PKC $\alpha$ induced by cold stress. (D) TRPM8-siRNA, BCTC, BAPTA-AM, and GSK3 $\beta$-siRNA inhibited the phosphorylation of GSK3 $\beta$ induced by cold stress. ${ }^{*} \mathrm{P}<0.01$ compared with the control group; ${ }^{*} \mathrm{P}<0.05$ compared with the cold stress group; $\wedge$ P $>0.05$ compared with the cold stress group. These data are presented as the means $\pm \mathrm{SD}(\mathrm{n}=5)$. 16HBE, human bronchial epithelial; TRPM8, transient receptor potential melastatin 8 ; siRNA, small interfering RNA; GSK3 $\beta$, glycogen synthase kinase $3 \beta$.

$\mathrm{AM}$, or safingol before cold stimulation. As shown in Figures 6,7, CIRP localized within the cytoplasm after cold stress but resided in the nucleus after treatment with TRPM8-siRNA, GSK3 $\beta$-siRNA, BCTC, BAPTA-AM, and safingol. Figure 8 shows that TRPM8-siRNA, BCTC,
BAPTA-AM, safingol, and GSK3 $\beta$-siRNA also reduced TNF- $\alpha$, IL-1 $\beta$, IL-8, IL-6 mRNA, and protein expression induced by cold stress. These results suggested that CIRP migration from the nucleus to the cytoplasm was required for inflammatory responses induced by cold stress. 
A

B
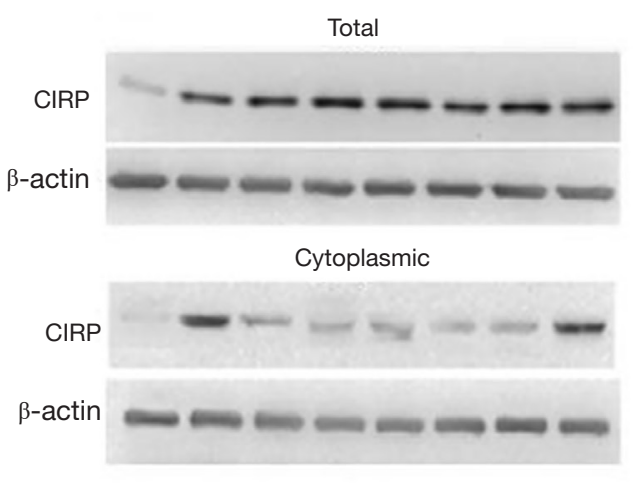

C

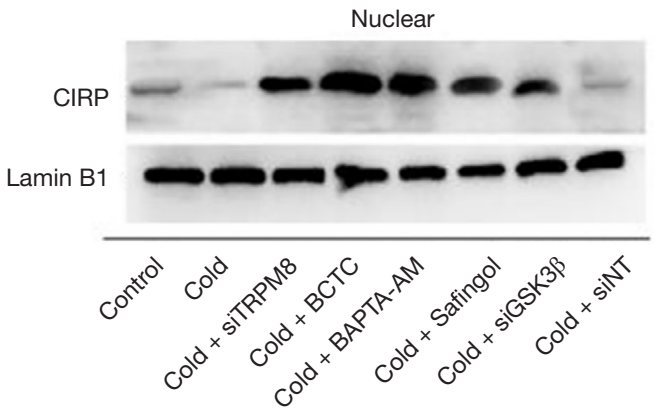

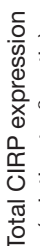
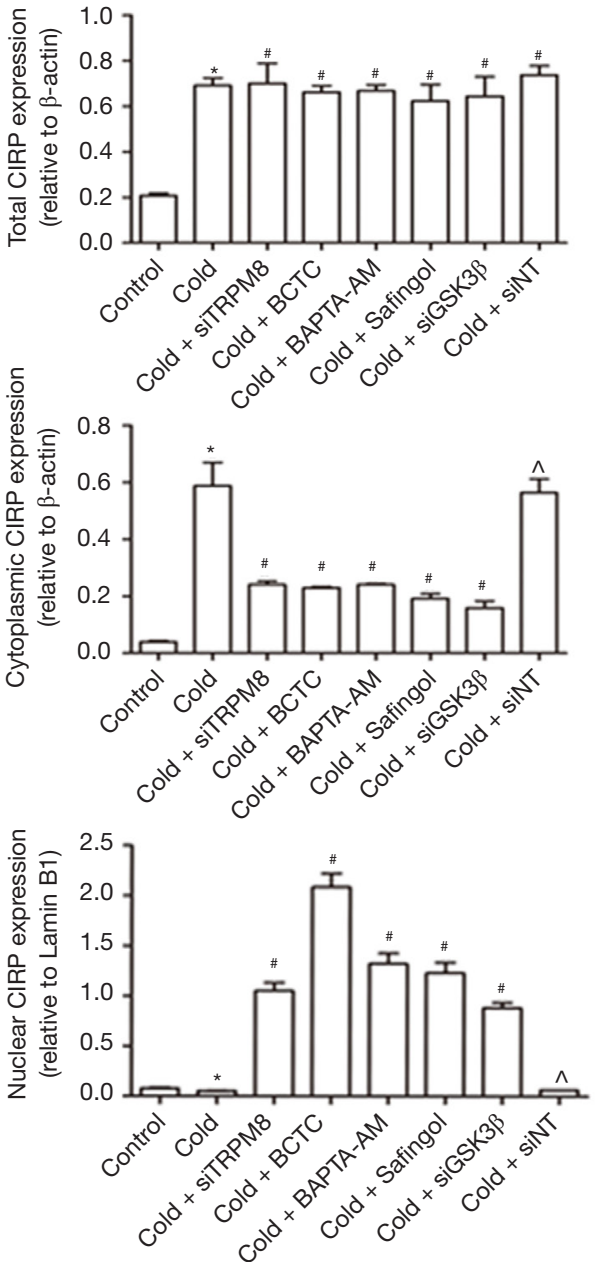

Figure 6 Western blot analysis for the expression of CIRP protein in 16HBE cells. Cells were transfected with TRPM8-siRNA, GSK3ßsiRNA, or siNT, or pretreated with TRPM8 inhibitor BCTC $(15 \mu \mathrm{M}),\left(\mathrm{Ca}^{2+}\right)_{\mathrm{i}}$ chelating agent BAPTA-AM $(10 \mu \mathrm{M})$, or PKC $\alpha$ specific inhibitor safingol $(30 \mu \mathrm{M})$ for 30 minutes before cold stress $\left(18^{\circ} \mathrm{C}, 12\right.$ hours). (A) At the cellular level, compared with the cold group, the expression of CIRP increased by cold stress were not decreased by TRPM8-siRNA, BCTC, BAPTA-AM, safingol, or GSK3 $\beta$-siRNA ( $\mathrm{P}>0.05$, there was no statistical significance). (B,C) After subcellular fractionation, the expression of nuclear CIRP was markedly increased, while cytoplasmic CIRP was decreased in the siTRPM8, BCTC, BAPTA-AM, safingol, and siGSK3 $\beta$ groups compared with the cold group. ${ }^{*} \mathrm{P}<0.01$ compared with the control group; ${ }^{*} \mathrm{P}<0.05$ compared with the cold stress group; ${ }^{\wedge} \mathrm{P}>0.05$ compared with the cold stress group. These data are presented as the means $\pm \mathrm{SD}(\mathrm{n}=5)$. CIRP, cold-inducible RNA-binding protein; 16HBE, human bronchial epithelial; TRPM8, transient receptor potential melastatin 8; siRNA, small interfering RNA; GSK3 $\beta$, glycogen synthase kinase $3 \beta$.

\section{Discussion}

The results of this study showed that apart from increased CIRP synthesis and its migration from the nucleus to the cytoplasm in NHBE cells, cold stress also induced inflammation responses through CIRP migration from the nucleus to the cytoplasm via the TRPM $8 /\left(\mathrm{Ca}^{2+}\right) / \mathrm{PKC} \alpha /$ GSK3 $\beta$ pathway. These data support the discovery that increased CIRP and inflammatory factor (IL-1 $\beta$, IL-6, IL8 , and $\mathrm{TNF}-\alpha)$ production promoted by cold stress are blocked by siCIRP. Inhibition of activation of the TRPM8/ $\left(\mathrm{Ca}^{2+}\right) / \mathrm{PKC} \alpha / \mathrm{GSK} 3 \beta$ signaling pathway did not decrease the upregulation of CIRP induced by cold stress, but it attenuated CIRP expression in the cytoplasm and reduced expression of the above inflammatory factors.

CIRP was the first cold shock protein to be identified. 


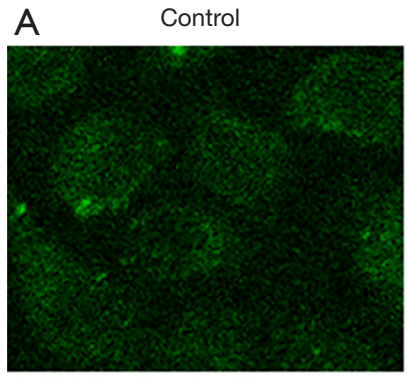

B Cold
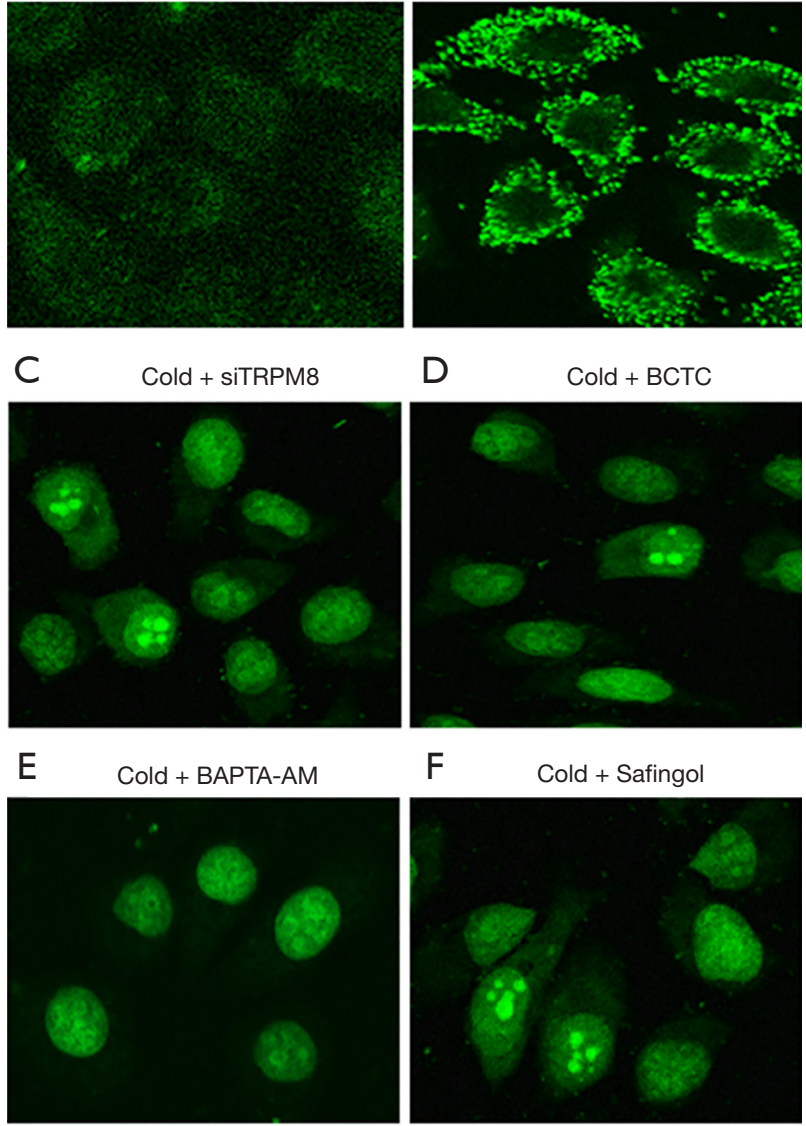

D Cold + BCTC

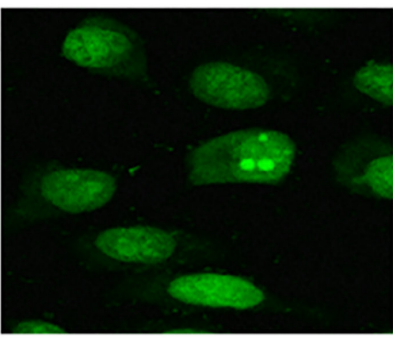

F Cold + Safingol
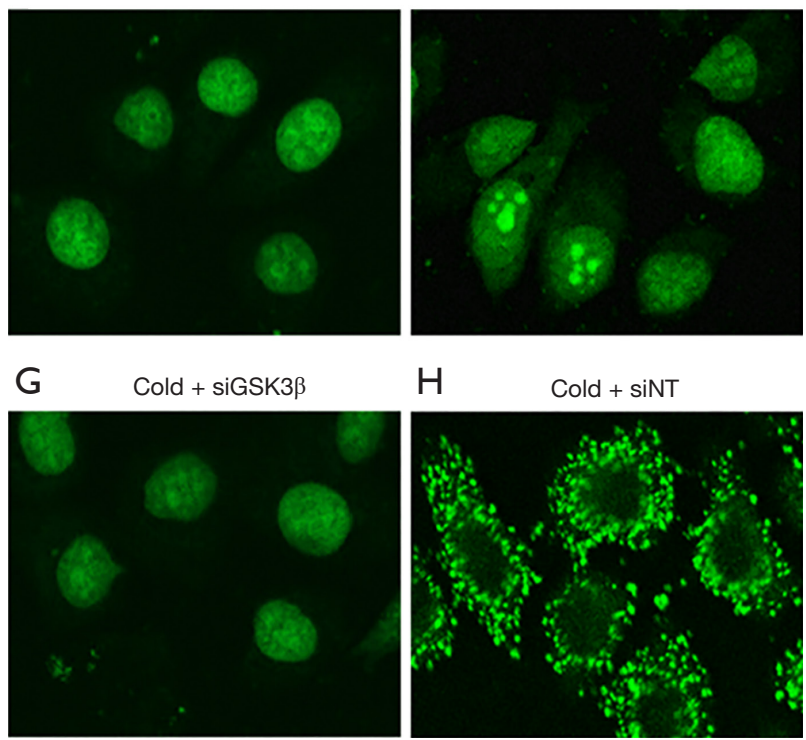

$\mathrm{H} \quad$ Cold + siNT

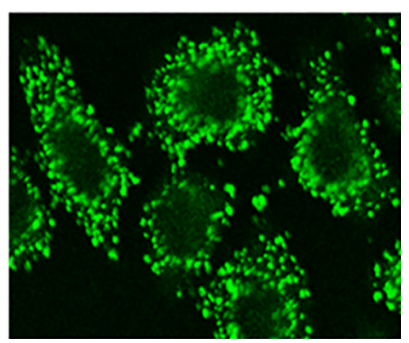

Figure 7 CLSM for the expression of CIRP protein in 16HBE cells. Cells were pretreated with or without siRNA, or pretreated with the TRPM8 inhibitors BCTC $(15 \mu \mathrm{M}),\left(\mathrm{Ca}^{2+}\right)_{\mathrm{i}}$ chelating agent BAPTA-AM $(10 \mu \mathrm{M})$, or PKC $\alpha$ specific inhibitor safingol for 30 minutes and then exposed to cold air $\left(18^{\circ} \mathrm{C}, 12\right.$ hours). Intracellular CIRP protein expression in $16 \mathrm{HBE}$ cells was detected by CLSM. The cellular CIRP protein expression in each group was detected using the CIRP antibody and fluorescein isothiocyanate (green) goat anti-mouse IgG, magnification $\times 800$. The results showed that cold stress $\left(18^{\circ} \mathrm{C}\right)$ significantly increased CIRP protein expression, which was enriched in the cytoplasm compared with the control group $\left(37^{\circ} \mathrm{C}\right)$. However, the cells treated with TRPM8-siRNA, TRPM8 inhibitor BCTC, $\left(\mathrm{Ca}^{2+}\right)_{\mathrm{i}}$ chelating agent BAPTA-AM, PKC $\alpha$ specific inhibitor safingol, or GSK3 $\beta$-siRNA exhibited remarkably decreased cytosolic CIRP expression with higher nuclear CIRP expression compared with the cold stress group and the non-target siRNA group. (A) The control group ( $37{ }^{\circ} \mathrm{C}$ ); (B) the cold stress group $\left(18{ }^{\circ} \mathrm{C}\right)$; $(\mathrm{C})$ the cold stress plus TRPM8-siRNA group; (D) the cold stress plus BCTC group; (E) the cold stress plus BAPTA-AM group; (F) the cold stress plus safingol group; $(\mathrm{G})$ the cold stress plus GSK3 $\beta$-siRNA group; (H) the cold stress plus nontarget siRNA group. CLSM, confocal laser-scanning microscopy. CLSM, confocal laser-scanning microscopy; CIRP, cold-inducible RNAbinding protein; 16HBE, human bronchial epithelial; siRNA, small interfering RNA; TRPM8, transient receptor potential melastatin 8; IgG, immunoglobulin G; GSK3 $\beta$, glycogen synthase kinase $3 \beta$. 

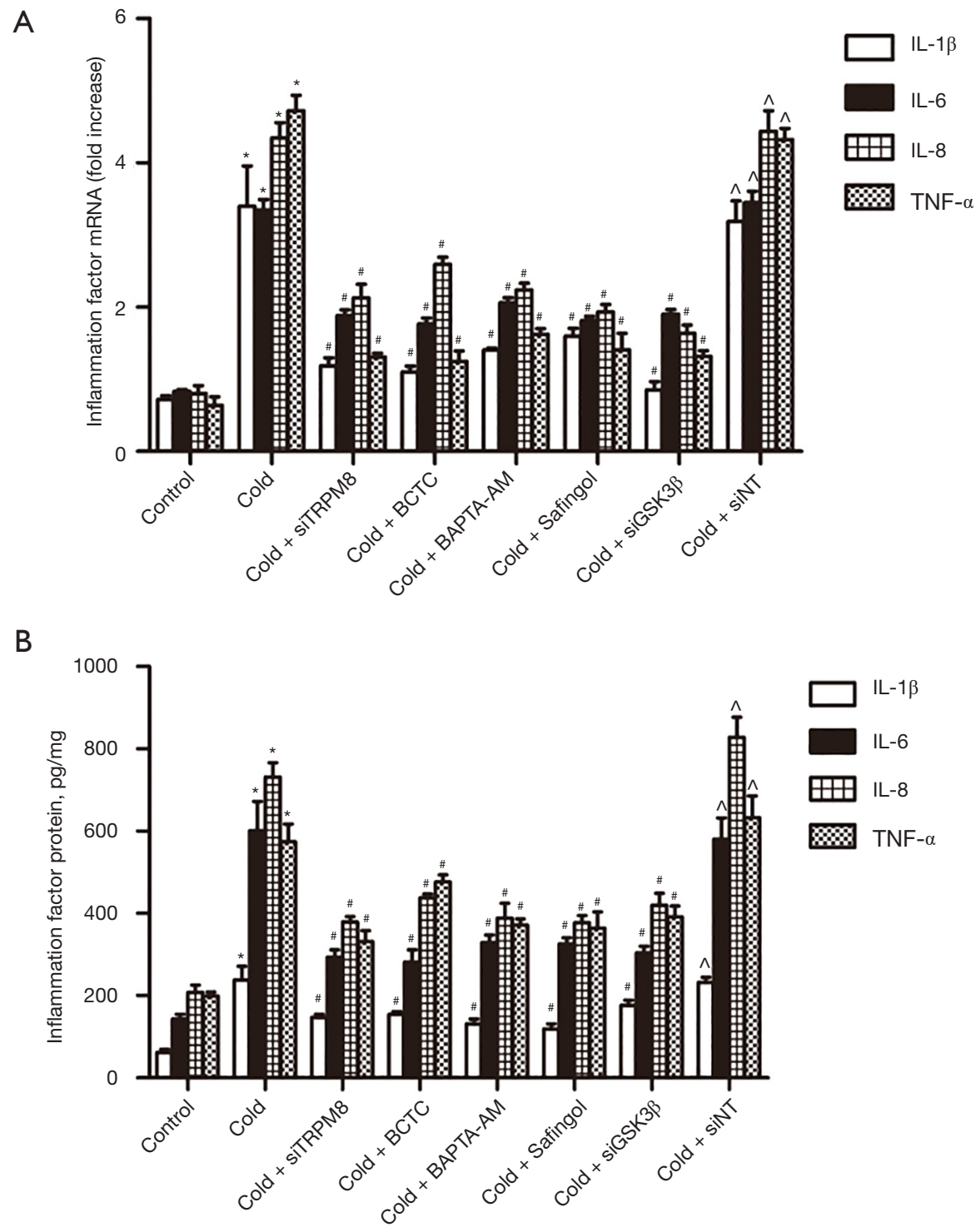

Figure 8 TRPM8/PKC $\alpha / G S K 3 \beta$ activation contributes to cold stress promoting effects on inflammatory response. Cells were pretreated with or without siRNA, or pretreated with the TRPM8 inhibitors BCTC $(15 \mu \mathrm{M}),\left[\mathrm{Ca}^{2+}\right]_{\mathrm{i}}$ chelating agent BAPTA-AM $(10 \mu M)$, or PKC $\alpha$ specific inhibitor safingol for 30 minutes and then exposed to cold air $\left(18^{\circ} \mathrm{C}, 12\right.$ hours). RT-PCR and ELISA were used to test the expression of inflammatory factor (IL-1 $\beta$, IL-6, IL-8, and TNF- $\alpha$ ) mRNA and protein, respectively. (A) Cold stress enhanced IL-1 $\beta$, IL-6, IL-8, and TNF- $\alpha$ mRNA expression, while siTRPM8, BCTC, BAPTA-AM, safingol, and siGSK3 $\beta$ significantly decreased these cold-induced responses. (B) Cold stress enhanced IL-1 $\beta$, IL-6, IL-8, and TNF- $\alpha$ protein expression, while siTRPM8, BCTC, BAPTA-AM, safingol, and siGSK3 $\beta$ significantly decreased these cold-induced responses. ${ }^{*} \mathrm{P}<0.01$ compared with the control group; ${ }^{\#} \mathrm{P}<0.05$ compared with the cold stress group; $\wedge \mathrm{P}>0.05$ compared with the cold stress group (there was no significance). The data in the column graph are the means $\pm \mathrm{SD}$ ( $\mathrm{n}=5$ ). TRPM8, transient receptor potential melastatin 8; GSK3 $\beta$, glycogen synthase kinase 3 $\beta$; siRNA, small interfering RNA; RT-PCR, real-time polymerase chain reaction; IL-1 $\beta$, interleukin- $1 \beta$; IL-6, interleukin-6; IL-8, interleukin-8; TNF- $\alpha$, tumor necrosis factor- $\alpha$. 
Previous studies have found that CIRP inhibited cell death from UV, moderate hypothermia, and genotoxic stress $(6,7,37)$ and also significantly decreased DNA damage and $\mathrm{H}_{2} \mathrm{O}_{2}$-inducible neural cell apoptosis $(9,38)$. In contrast to these protective actions, more and more studies have reported that CIRP is secreted into circulation, activating detrimental endogenous proinflammatory responses (39). Rajayer et al. reported that CIRP secreted by BV2 cells exposed to alcohol induced proinflammatory (TNF- $\alpha$ and IL-1 $\beta$ ) expression (10). Zhou et al. also found that the release of CIRP from microglia promoted TNF- $\alpha$ production and modulated brain inflammation, subsequently leading to neural damage (40). In addition, Davis et al. reported that CIRP promoted an inflammatory reaction under hemorrhagic shock and sepsis (41). Sakurai et al. showed that CIRP modulated apoptosis and the expression of IL-23 and TNF- $\alpha$ to enhance intestinal inflammation and colorectal tumors (42), and also that CIRP accelerated tumorigenesis of liver cancer by regulating reactive oxygen species (ROS) accumulation under oxidative stress (43). These findings indicate that CIRP has numerous biological functions. We found that the expression of CIRP mRNA and protein began to increase at $32^{\circ} \mathrm{C}$, peaked at $18{ }^{\circ} \mathrm{C}$, and began to decrease at $15{ }^{\circ} \mathrm{C}$. CIRP protein expression changed over time, and the plateau expression was observed at 12 hours. CIRP mRNA expression peaked at 8 hours and did not further increase with the extension of time. The maximum time interval was earlier for CIRP mRNA expression (8 hours) induced by cold air than for CIRP protein expression (12 hours), which indicated that cold air has prolonged effect on CIRP protein expression than mRNA expression Figure 1). In addition, our experiments showed that cold stress increased inflammatory factor (TNF- $\alpha$, IL-1 $\beta$, IL-8, and IL-6) synthesis, which was reduced by siCIRP (Figure 2). These results revealed that the cold air increased CIRP production in a temperatureand time-dependent manner, and that CIRP was partly necessary for cold stress-inducible inflammatory responses to cold stress. CIRP, a well-known stress protein, migrates from the nucleus to the cytoplasm under physiological and environmental stress. Hence, we determined the subcellular localization of CIRP in 16HBE cells. CIRP was observed in the nucleus under normal conditions but detected in cytoplasm after cold stimulation (Figure 3), which demonstrated that CIRP could migrate from the nucleus to the cytoplasm upon cold stress. This result is consistent with the findings of previous reports $(7,8,14,44)$. Further, we found that CIRP expression was increased significantly after cold treatment. These observations indicate that cold stress might play a dual role in CIRP regulation.

De Leeuw et al. (15) found that phosphorylation of GSK3 $\beta$ kinase promoted the movement of CIRP from the nucleus to the cytoplasm under ER stress and cytoplasmic stress. Other studies have also indicated that CIRP migrated from the nucleus to the cytoplasm either through its arginine methylation or phosphorylation by GSK3 $\beta$ kinase (7). GSK3 $\beta$ is a multifunctional serine/threonine protein kinase which is involved in a number of cell signaling pathways, playing important roles in glycogen metabolism, cell differentiation, cell proliferation, and gene expression $(45,46)$. Hartigan et al. reported that transient increases in intracellular calcium increased Tyr216 phosphorylation of GSK3 $\beta$ (47). Research by both Gao et al. and Park et al. found that activated PKC could phosphorylate GSK3 $\beta$ as well $(32,33)$. Sabnis et al. reported that a functional truncated TRPM8 variant was detected in NHBE cells (26). Additionally, it has been reported that truncated TRPM8 contains a voltage sensor region, the transmembrane segment 4 and the segment 4/segment 5 linker, which is involved in cold sensation. These findings illustrate that TRPM8 expressed in NHBE cells has an ability to perceive cold stimulation $(48,49)$ and can be activated, resulting in an obvious increase in $\left(\mathrm{Ca}^{2+}\right)_{i}$ concentration and phosphorylation of PKC $\alpha$. Based on this, our study aimed to determine whether TRPM8, PKC $\alpha$, or GSK3 $\beta$ were related to CIRP movement under cold conditions.

Figure 4 shows that cold temperature induced a significant increase in $\left(\mathrm{Ca}^{2+}\right)_{\mathrm{i}}$ concentration, and increased $\left(\mathrm{Ca}^{2+}\right)_{\mathrm{i}}$ concentration was inhibited by TRPM8 siRNA, specific TRPM8 antagonist BCTC, as well as by $\left(\mathrm{Ca}^{2+}\right)_{\mathrm{i}}$ chelating agent BAPTA-AM. These results are consistent with those of a previous study (23) showing that the TRPM8 channel can be activated by cold stimulation and that NHBE cells sense cold stimulus primarily due to the TRPM8 channel. Western blotting (Figure 5) showed that cold stimulation augmented the phosphorylation of PKC $\alpha$ and GSK3 $\beta$, and the above phenomena were blocked by TRPM8 siRNA, BCTC, BAPTA-AM, and safingol (a specific PKC inhibitor). These results suggested that cold stimulation-induced activation of $\mathrm{PKC} \alpha / \mathrm{GSK} 3 \beta$ is highly dependent on the TRPM8 channel. Next, we tested whether TRPM $8 /\left(\mathrm{Ca}^{2+}\right) / \mathrm{PKC} \alpha / \mathrm{GSK} 3 \beta$ involved CIRP migration from the nucleus to the cytoplasm. At the cellular level (Figure 6A), cold stimulation significantly induced CIRP expression in 16HBE cells, and the overproduction 
of CIRP was not reduced by TRPM8 siRNA, BCTC, BAPTA-AM, safingol, or GSK3 $\beta$ siRNA. At the subcellular level (Figure 6B,6C), 16HBE cells pretreated with TRPM8 siRNA, BCTC, BAPTA-AM, safingol, or GSK3 $\beta$ siRNA significantly attenuated CIRP expression in the cytoplasm, with overproduction of CIRP in the nucleus. These results demonstrated that cold stimulus increased CIRP synthesis and promoted CIRP movement from the nucleus to the cytoplasm via the TRPM8/(Ca $\left.{ }^{2+}\right)_{i} / \mathrm{PKC} \alpha / \mathrm{GSK} 3 \beta$ signaling pathway. In addition, the changes in CIRP expression were observed directly by CLSM, strengthening the credibility of our results. As shown in Figure 7, CIRP expression was remarkably increased under cold conditions and was mainly located in the cytoplasm. However, transfection of the $16 \mathrm{HBE}$ cells with TRPM8 siRNA or GSK3 $\beta$ siRNA remarkably decreased cytoplasmic CIRP expression. Similar to previous experimental results, incubation with the TRPM8 specific inhibitor BCTC, $\left(\mathrm{Ca}^{2+}\right)_{\mathrm{i}}$ chelating agent BAPTA-AM, or PKC $\alpha$ specific inhibitor safingol prior to cold stimulation notably reduced cytoplasmic CIRP expression with nuclear CIRP upregulation, confirming previous conclusions. Finally, we found that limiting CIRP movement from the nucleus to the cytoplasm by inhibiting the TRPM $8 /\left(\mathrm{Ca}^{2+}\right)_{\mathrm{i}} / \mathrm{PKC} \alpha / \mathrm{GSK} 3 \beta$ signaling pathway attenuated the expression levels of IL-1 $\beta$, IL-6, IL-8, and TNF- $\alpha$ (Figure 8). These data suggest that the inflammatory factor expression modulated by CIRP was dependent on CIRP migration from the nucleus to the cytoplasm. While it is widely accepted that CIRP can to bind RNAs and to modulate them at the post-transcriptional level via increasing mRNA stabilization, our previous research showed that CIRP mediated airway mucin by interaction with TLR4 directly. Thus, it would be interesting to study whether CIRP regulating inflammatory factor expression is a direct or indirect effect of CIRP.

In conclusion, the present study showed that cold stress upregulated CIRP mRNA and protein expression in $16 \mathrm{HBE}$ cells and promoted CIRP movement from the nucleus to the cytoplasm via TRPM $8 /\left(\mathrm{Ca}^{2+}\right) / \mathrm{PKC} \alpha /$ GSK $3 \beta$. CIRP mediated inflammatory factor (IL-1 $\beta$, IL-6, IL-8, and TNF- $\alpha$ ) expression induced by cold stress through CIRP migration from the nucleus to the cytoplasm. To our knowledge, this study is the first to demonstrate the mechanism of CIRP migration from the nucleus to the cytoplasm upon cold stress in bronchial airway epithelial cells. Although we have clarified how CIRP migrates from the nucleus to the cytoplasm, the exact molecular mechanisms by which cytosolic CIRP mediates inflammatory factor expression are unknown. Thus, more studies are needed.

\section{Acknowledgments}

Funding: This study was supported by a grant from the National Natural Science Foundation of China (No. 81660010 and 81611530713$)$.

\section{Footnote}

Reporting Checklist: The authors have completed the MDAR reporting checklist. Available at https://dx.doi. org/10.21037/atm-21-4447

Data Sharing Statement: Available at https://dx.doi. org/10.21037/atm-21-4447

Conflicts of Interest: All authors have completed the ICMJE uniform disclosure form (available at https://dx.doi. org/10.21037/atm-21-4447). All authors report a grant from the National Natural Science Foundation of China (No. 81660010 and 81611530713 ). The authors have no other conflicts of interest to declare.

Ethical Statement: The authors are accountable for all aspects of the work in ensuring that questions related to the accuracy or integrity of any part of the work are appropriately investigated and resolved.

Open Access Statement: This is an Open Access article distributed in accordance with the Creative Commons Attribution-NonCommercial-NoDerivs 4.0 International License (CC BY-NC-ND 4.0), which permits the noncommercial replication and distribution of the article with the strict proviso that no changes or edits are made and the original work is properly cited (including links to both the formal publication through the relevant DOI and the license). See: https://creativecommons.org/licenses/by-nc-nd/4.0/.

\section{References}

1. Liu J, Xue J, Zhang H, et al. Cloning, expression, and purification of cold-inducible RNA-binding protein and its neuroprotective mechanism of action. Brain Res 2015;1597:189-95.

2. Nishiyama H, Higashitsuji $\mathrm{H}$, Yokoi $\mathrm{H}$, et al. Cloning and characterization of human CIRP (cold-inducible RNA- 
binding protein) cDNA and chromosomal assignment of the gene. Gene 1997;204:115-20.

3. Sumitomo Y, Higashitsuji H, Higashitsuji H, et al. Identification of a novel enhancer that binds Sp1 and contributes to induction of cold-inducible RNA-binding protein (CIRP) expression in mammalian cells. BMC Biotechnol 2012;12:72.

4. Clifton GL, Miller ER, Choi SC, et al. Lack of effect of induction of hypothermia after acute brain injury. N Engl J Med 2001;344:556-63.

5. Gualerzi CO, Giuliodori AM, Pon CL. Transcriptional and post-transcriptional control of cold-shock genes. J Mol Biol 2003;331:527-39.

6. Sheikh MS, Carrier F, Papathanasiou MA, et al. Identification of several human homologs of hamster DNA damage-inducible transcripts. Cloning and characterization of a novel UV-inducible cDNA that codes for a putative RNA-binding protein. J Biol Chem 1997;272:26720-6.

7. Wellmann S, Bührer C, Moderegger E, et al. Oxygenregulated expression of the RNA-binding proteins RBM3 and CIRP by a HIF-1-independent mechanism. J Cell Sci 2004;117:1785-94.

8. Pan F, Zarate J, Choudhury A, et al. Osmotic stress of salmon stimulates upregulation of a cold inducible RNA binding protein (CIRP) similar to that of mammals and amphibians. Biochimie 2004;86:451-61.

9. Li S, Zhang Z, Xue J, et al. Cold-inducible RNA binding protein inhibits $\mathrm{H}_{2} \mathrm{O}_{2}$-induced apoptosis in rat cortical neurons. Brain Res 2012;1441:47-52.

10. Rajayer SR, Jacob A, Yang WL, et al. Cold-inducible RNA-binding protein is an important mediator of alcoholinduced brain inflammation. PLoS One 2013;8:e79430.

11. Qiang X, Yang WL, Wu R, et al. Cold-inducible RNAbinding protein (CIRP) triggers inflammatory responses in hemorrhagic shock and sepsis. Nat Med 2013;19:1489-95.

12. Nishiyama H, Itoh K, Kaneko Y, et al. A glycinerich RNA-binding protein mediating cold-inducible suppression of mammalian cell growth. J Cell Biol 1997;137:899-908.

13. Nishiyama H, Danno S, Kaneko Y, et al. Decreased expression of cold-inducible RNA-binding protein (CIRP) in male germ cells at elevated temperature. Am J Pathol 1998;152:289-96.

14. Matsumoto K, Aoki K, Dohmae N, et al. CIRP2, a major cytoplasmic RNA-binding protein in Xenopus oocytes. Nucleic Acids Res 2000;28:4689-97.

15. De Leeuw F, Zhang T, Wauquier C, et al. The coldinducible RNA-binding protein migrates from the nucleus to cytoplasmic stress granules by a methylation-dependent mechanism and acts as a translational repressor. Exp Cell Res 2007;313:4130-44.

16. Chen L, Ran D, Xie W, et al. Cold-inducible RNAbinding protein mediates cold air inducible airway mucin production through TLR4/NF- $\mathrm{B}$ signaling pathway. Int Immunopharmacol 2016;39:48-56.

17. Thandapani $\mathrm{P}, \mathrm{O}^{\prime}$ Connor TR, Bailey TL, et al. Defining the RGG/RG motif. Mol Cell 2013;50:613-23.

18. Yang R, Zhan M, Nalabothula NR, et al. Functional significance for a heterogenous ribonucleoprotein A18 signature RNA motif in the 3'-untranslated region of ataxia telangiectasia mutated and Rad3-related (ATR) transcript. J Biol Chem 2010;285:8887-93.

19. McKemy DD, Neuhausser WM, Julius D. Identification of a cold receptor reveals a general role for TRP channels in thermosensation. Nature 2002;416:52-8.

20. Peier AM, Moqrich A, Hergarden AC, et al. A TRP channel that senses cold stimuli and menthol. Cell 2002;108:705-15.

21. Nealen ML, Gold MS, Thut PD, et al. TRPM8 mRNA is expressed in a subset of cold-responsive trigeminal neurons from rat. J Neurophysiol 2003;90:515-20.

22. Li M, Li Q, Yang G, et al. Cold temperature induces mucin hypersecretion from normal human bronchial epithelial cells in vitro through a transient receptor potential melastatin 8 (TRPM8)-mediated mechanism. J Allergy Clin Immunol 2011;128:626-34.e1-5.

23. Almaraz L, Manenschijn JA, de la Peña E, et al. TRPM8. Handb Exp Pharmacol 2014;222:547-79.

24. Mälkiä A, Madrid R, Meseguer V, et al. Bidirectional shifts of TRPM8 channel gating by temperature and chemical agents modulate the cold sensitivity of mammalian thermoreceptors. J Physiol 2007;581:155-74.

25. Mahieu F, Owsianik G, Verbert L, et al. TRPM8independent menthol-induced $\mathrm{Ca} 2+$ release from endoplasmic reticulum and Golgi. J Biol Chem 2007;282:3325-36.

26. Sabnis AS, Shadid M, Yost GS, et al. Human lung epithelial cells express a functional cold-sensing TRPM8 variant. Am J Respir Cell Mol Biol 2008;39:466-74.

27. Liu B, Qin F. Functional control of cold- and mentholsensitive TRPM8 ion channels by phosphatidylinositol 4,5-bisphosphate. J Neurosci 2005;25:1674-81.

28. Rohács T, Lopes CM, Michailidis I, et al. PI(4,5)P2 regulates the activation and desensitization of TRPM8 channels through the TRP domain. Nat Neurosci 2005;8:626-34. 
29. Daniels RL, Takashima Y, McKemy DD. Activity of the neuronal cold sensor TRPM8 is regulated by phospholipase $\mathrm{C}$ via the phospholipid phosphoinositol 4,5-bisphosphate. J Biol Chem 2009;284:1570-82.

30. Puzianowska-Kuznicka M, Kuznicki J. The ER and ageing II: calcium homeostasis. Ageing Res Rev 2009;8:160-72.

31. Rebecchi MJ, Pentyala SN. Structure, function, and control of phosphoinositide-specific phospholipase C. Physiol Rev 2000;80:1291-335.

32. Gao X, Xu F, Zhang HT, et al. PKC $\alpha-G S K 3 \beta-N F-$ $\kappa \mathrm{B}$ signaling pathway and the possible involvement of TRIM2 1 in TRAIL-induced apoptosis. Biochem Cell Biol 2016;94:256-64.

33. Park SY, Kang MJ, Han JS. Neuronal NOS induces neuronal differentiation through a PKC $\alpha$-dependent GSK3 $\beta$ inactivation pathway in hippocampal neural progenitor cells. Mol Neurobiol 2017;54:5646-56.

34. Kim L, Kimmel AR. GSK3, a master switch regulating cell-fate specification and tumorigenesis. Curr Opin Genet Dev 2000;10:508-14.

35. Lumme A, Haahtela T, Ounap J, et al. Airway inflammation, bronchial hyperresponsiveness and asthma in elite ice hockey players. Eur Respir J 2003;22:113-7.

36. Sheel AW, MacNutt MJ, Querido JS. The pulmonary system during exercise in hypoxia and the cold. Exp Physiol 2010;95:422-30.

37. Yang C, Carrier F. The UV-inducible RNA-binding protein A18 (A18 hnRNP) plays a protective role in the genotoxic stress response. J Biol Chem 2001;276:47277-84.

38. Lee HN, Ahn SM, Jang HH. Cold-inducible RNAbinding protein, CIRP, inhibits DNA damage-induced apoptosis by regulating p53. Biochem Biophys Res Commun 2015;464:916-21.

39. Godwin A, Yang WL, Sharma A, et al. Blocking coldinducible RNA-binding protein protects liver from ischemia-reperfusion injury. Shock 2015;43:24-30.

Cite this article as: Mao LP, Jiao Y, Xiang JH, Luo XW, He Q, Ran DH, Xu Q, Lang CH, Chen LX. Cold-inducible RNAbinding protein migrates from the nucleus to the cytoplasm under cold stress in normal human bronchial epithelial cells via TRPM8-mediated mechanism. Ann Transl Med 2021;9(18):1470. doi: 10.21037/atm-21-4447
40. Zhou M, Yang WL, Ji Y, et al. Cold-inducible RNAbinding protein mediates neuroinflammation in cerebral ischemia. Biochim Biophys Acta 2014;1840:2253-61.

41. Davis MS, Freed AN. Repeated hyperventilation causes peripheral airways inflammation, hyperreactivity, and impaired bronchodilation in dogs. Am J Respir Crit Care Med 2001;164:785-9.

42. Sakurai T, Kashida H, Watanabe T, et al. Stress response protein cirp links inflammation and tumorigenesis in colitis-associated cancer. Cancer Res 2014;74:6119-28.

43. Sakurai T, Yada N, Watanabe T, et al. Cold-inducible RNA-binding protein promotes the development of liver cancer. Cancer Sci 2015;106:352-8.

44. Anderson P, Kedersha N. RNA granules. J Cell Biol 2006;172:803-8.

45. Saito T, Sugimoto K, Adachi Y, et al. Cloning and characterization of amphibian cold inducible RNA-binding protein. Comp Biochem Physiol B Biochem Mol Biol 2000;125:237-45.

46. Wang H, Brown J, Martin M. Glycogen synthase kinase 3: a point of convergence for the host inflammatory response. Cytokine 2011;53:130-40.

47. Hartigan JA, Johnson GV. Transient increases in intracellular calcium result in prolonged site-selective increases in Tau phosphorylation through a glycogen synthase kinase 3beta-dependent pathway. J Biol Chem 1999;274:21395-401.

48. Bandell M, Dubin AE, Petrus MJ, et al. High-throughput random mutagenesis screen reveals TRPM8 residues specifically required for activation by menthol. Nat Neurosci 2006;9:493-500.

49. Voets T, Owsianik G, Janssens A, et al. TRPM8 voltage sensor mutants reveal a mechanism for integrating thermal and chemical stimuli. Nat Chem Biol 2007;3:174-82.

(English Language Editor: A. Muijlwijk) 